\title{
PEMBIBITAN DAN PENGGEMUKAN KAMBING "LOKETAWA" PENGHASIL DAGING DAN SUSU RAKITAN TEKNOBREEDING DAN TEKNOFATTENING PAKAN TANPA HIJAUAN (COMPLETE FEED)
}

\section{GOAT BREEDING AND FATTING “LOKETAWA" PRODUCING MEAT AND TEKNOBREEDING AND TEXTNOFATTENING MILK (COMPLETE FEED}

\author{
Wurlina \\ Departemen ReproduksiVeteriner Fakultas Kedokteran Hewan Universitas Airlangga \\ Kampus C Unair.Jl. Mulyorejo Surabaya 60115 Telp.031-5992785, Fax. 031-5993015 Email: wurlina_made@yahoo.co.id
}

\section{Rimayanti}

Departemen ReproduksiVeteriner Fakultas Kedokteran Hewan Universitas Airlangga Kampus C Unair.Jl. Mulyorejo Surabaya 60115 Telp.031-5992785, Fax. 031-5993015

\section{Mas'ud Hariadi}

Departemen ReproduksiVeteriner Fakultas Kedokteran Hewan Universitas Airlangga Kampus C Unair.Jl. Mulyorejo Surabaya 60115 Telp.031-5992785, Fax. 031-5993015

\section{Dewa Ketut Meles}

Departemen Ilmu Kedokteran DasarVeteriner Fakultas Kedokteran Hewan Universitas Airlangga Kampus C Unair.Jl. Mulyorejo Surabaya 60115 Telp.031-5992785, Fax. 031-5993015

\begin{abstract}
Abstrak
Ipteks bagi Masyarakat yang dilakukan pada kelompok usaha pembibitan dan penggemukan kambing "Loketawa" bertujuan: 1) memperbaiki genetik kambing lokal melalui IB menggunakan pejantan Etawa 2) mendapatkan induk kambing birahi bersamaam dilakukan sinkronisasi birahi 3) mendapatkan induk kambing bunting dari setahun sekali menjadi 2 kali setahun 4) meningkatkan jumlah anak dari 1 ekor sekelahiran menjadi 3-4 ekor sekelahiran menggunakan teknik superovulasi 5) menekan biaya produksi, membuat pakan tanpa hijauan dan growth promotor. Metode pelaksanaan yang digunakan adalah 1) memperkenalkan pejantan Etawa penghasil daging dan susu 2) sinkronisasi birahi menggunakan PGF2 $\alpha$ 3) superovulasi menggunakan hormon FSH dan LH 4) IB pada kambing menggunakan semen kambing Etawa, 5) pengolahan pakan tanpa hijauan dan growth promoter. Hasilnya adalah sebagai berikut : 1) sebanyak 20 ekor induk kambing mengalami birahi bersamaan menggunakan PGF2 $\alpha$ sebesar 100\%, Inseminasi buatan pada 10 ekor induk kambing tanpa super ovulasi mempunyai anak rata-rata 1,6 ekor sekelahiran, sedangkan Inseminasi buatan pada 10 ekor induk kambing dengan super ovulasi mempunyai anak rata-rata 3 ekor sekelahiran, 3) peningkatan berat badan kambing ratarata 252,35 gram/ekor perhari.
\end{abstract}

Kata kunci: inseminasi buatan, kambing loketawa, pakan lengkap, sinkronisasi, superovulalasi.

\begin{abstract}
IbM to business gorup in the goat breeding and fattening "Loketawa" aims to: 1) improve local goat genetics through IB using Etawa stud 2) obtain mother goats lust together done synchronization lusts 3) get mother goat bunting from once a year to 2 times a year 4) increase the number of children from 1 birth to 3-4 births using superovulation techniques 5) reduce production costs, make feed without forage and growth promotor. The method of implementation used 1) introducing stud Etawa meat and milk producers 2) synchronization lust using PGF2a 3) superovulation using hormone FSH and LH 4) IB on goats using Etawa goat cuttings, 5) the processing of feed without forage and growth promoter. The results are as follows: 1) as many as 20 heads of goats are simultaneously using $100 \%$ PGF2 $\alpha$, artificial insemination on 10 heads of goats without super ovulation has an average child of 1.6 births, while artificial insemination on 10 goats with super ovulation having an average child 3 births, 3) an average goat weight increase of 252.35 grams per day.
\end{abstract}

Keywords: Loketawa goat, synchronization, superovulalation, artificial insemination, complete feed 


\section{PENDAHULUAN}

Salah satu komoditas peternakan yang dimiliki hampir di seluruh dunia yaitu kambing dan Indonesia merupakan salah satu negara yang dapat mengendalikan produksi ternak kambing potong untuk menghadapi globalisasai hasil peternakan 2020. Indonesia merupakan negara tropis dengan sumber alam yang mendukung, yaitu memiliki iklim tropis yang sesuai bagi pengembangan ternak kambing, tanah yang luas dan produksi hijauan yang berlimpah pada musim hujan cukup untuk memelihara 100 juta ternak kambing atau 10 kali dari populasi yang ada sekarang. Namun pada musim kemarau, hijauan berkurang sehingga para peternak enggan untuk beternak belum lagi terjadinya perubahan musim sehingga membingungkan peternak (Wurlina dkk., 2012, Junjungan dkk., 2002). Untuk mengantisipasi kekurangan hijauan saat musim kemarau dibuatlah pakan ternak tanpa hijauan. Keunggulan pakan tanpa hijauan (complete feed $=\mathrm{CF}$ ) yaitu mengandung nutrisi yang seimbang dengan harga murah. Hal ini disebabkan complete feed dibuat dari limbah pertanian, limbah perkebunan serta limbah agroindustri ditambah suplementasi yang bernilai nutrisi tinggi. Keunggulan lain pakan tanpa hijauan adalah: 1) peningkatan berat badan kambing 200-250 gram/hari/ekor 2) ekonomis dan praktis (1 ekor kambing butuh $2 \mathrm{~kg}$ ) dengan harga pakan Rp. 1200 - Rp.1500,-/kg 3) waktu penggemukan pendek (4-5 bulan) 4) hemat tenaga kerja (1 orang untuk 80- 100 ekor kambing) dan 5) mudah diaplikasikan (Wurlina dkk. 2012, Hariadi dkk. 2011). Limbah kulit nanas sewaktu musim hujan menyebabkan polusi selain bau juga banyaknya lalat yang dapat menyebabkan wabah penyakit terutama diare sehingga limbah kulit nanas diolah menjadi growth promotor untuk merangsang nafsu makan.

Penerapan teknologi inseminasi buatan pada ternak kambing PE menggunakan semen kambing PE akan dihasilkan anak kambing dengan pertumbuhan dan perkembangan berat badan cepat dan induk kambing sebagai penghasil susu. Idealnya kambing betina beranak dalam kurun waktu 6-7 bulan dengan jumlah anak dapat mencapai 4 ekor sekelahiran (Wurlina 1996; Wurlina 2002).

Untuk mendapatkan induk kambing birahi secara bersamaan dilakukan sinkronisasi birahi menggunakan PGF2 $\alpha$. Menurut Wurlina dkk. $(2005,2002)$ kambing di pedesaan ukurannya kecil sehingga dosis yang digunakan untuk sinkronisasi birahi adalah 4-5 mg/ekor. Cara penyuntikan agar mendapatkan kambing birahi secara serentak dalam suatu populasi yaitu dilakukan penyuntikan 2 kali dengan selang waktu 11 hari, selanjutnya inseminasi dilakukan pada birahi setelah penyuntikan PGF2 $\alpha$ kedua. Untuk mendapatkan anak kambing dengan jumlah 3-4 ekor sekelahiran dilakukan superovulasi menggunakan hormon PMSG dan HCG.

Permasalah ketersediaan bibit yaitu induk kambing yang bunting hanya mampu beranak setahun satu kali dengan jumlah anak 1-2 ekor sekelahiran. Padahal kambing dapat beranak setahun dua kali, hal ini dimungkinkan karena masa bunting kambing \pm 140 hari (4,7 bulan) sehingga dalam setahun dapat beranak dua kali. Kelahiran dapat dibuat kembar dua, tiga atau bahkan empat ekor melalui teknologi Inseminasi Buatan (IB). Untuk mendapatkan umur anak kambing yang hampir bersamaan induk kambing disinkronisasi birahi menggunakan PGF2 $\alpha$ serta dibuat superovulasi dengan menggunakan PMSG dan HCG (Wurlina 2012).

Permasalahan pakan adalah ketersediaan pakan hijauan terutama pada musim kemarau. Solusinya adalah pengolahan pakan kambing tanpa hijauan dengan memanfaatkan bahan baku pakan lokal melalui pemanfaatkan limbah pertanian (jerami padi, kulit batang kedelai, bonggol jagung, tumpi), limbah perkebunan (kulit kopi, kulit kakau, bungkil sawit, gaplek, klenteng), limbah pabrik (ampas tahu, ampas beer).

Tujuan kegiatan adalah sebagai berikut : 1) Penyerentakan birahi menggunakan PGF2 $\alpha$ 2) Superovulasi menggunakan PMSG dan HCG 3) Jumlah induk kambing yang bunting setelah dilakukan IB 4) Jumlah dan jenis kelamin anak kambing hasil IB 5) peningkatan berat badan pejantan digemukkan.

\section{METODE PELAKSANAAN}

Sebanyak 20 ekor induk kambing dilakukan sinkronisasi birahi menggunakan prostaglandin F2 $\alpha$ (PGF2 $\alpha$ ) dengan dosis $5 \mathrm{mg}$ /ekor secara intra muskuler. Penyuntikan PGF2 $\alpha$ dilakukan dua kali dengan selang waktu 11 hari. Induk kambing yang menunjukkan gejala birahi setelah penyuntikan PGF2 $\alpha$ pertama, tidak dilakukan inseminasi buatan. Inseminasi buatan dilakukan pada induk kambing yang menunjukkan gejala birahi setelah penyuntikan PGF2 $\alpha$ kedua menggunakan semen pejantan Etawa. Parameter yang diamati adalah jumlah induk kambing menunjukkan gejala birahi setelah penyuntikan PGF2 $\alpha$ pertama dan PGF2 $\alpha$ kedua. Sebanyak 10 ekor induk kambing dilakukan sinkronisasi birahi menggunakan PGF2 $\alpha$, dilakukan superovulasi menggunakan PMSG dosis 500 IU dan HCG 250 IU pada waktu yang sama. Induk kambing akan menunjukkan gelaja birahi 2-3 hari setelah penyuntikan PGF2 $\alpha$ kedua. Selanjutnya dilakukan Inseminasi buatan menggunakan semen dari pejantan Etawa. Parameter yang diamati adalah sebagai berikut: Jumlah induk kambing bunting setelah dilakukan superovulasi dan Jumlah dan jenis kelamin anak kambing yang dilahirkan hasil inseminasi buatan

\section{HASIL DAN PEMBAHASAN}

\section{Penyerentakan Birahi pada Induk Kambing}

Sebanyak 20 ekor induk kambing setelah dilakukan penyerentakan birahi menggunakan PGF2 $\alpha$ dosis $5 \mathrm{mg}$ /ekor 
secara intramuskuler. Penyuntikan dilakukan dua kali dengan interval 11 hari. Hasilnya dapat dilihat pada tabel 1.

Tabel 1. Penyerentakan birahi pada kambing menggunakan PGF $2 \alpha$

\begin{tabular}{ccc}
\hline \multirow{2}{*}{$\begin{array}{c}\text { Jumlah } \\
\text { induk } \\
\text { kambing }\end{array}$} & $\begin{array}{c}\text { Jumlah induk kambing birahi } \\
\text { penyuntikan } \\
\text { PGF2 } \alpha \text { pertama }\end{array}$ & $\begin{array}{c}\text { Birahi setelah } \\
\text { penyuntikan } \\
\text { PGF2 } \boldsymbol{\alpha} \text { kedua }\end{array}$ \\
\hline 20 ekor & 8 ekor $(40 \%)$ & 20 ekor $(100 \%)$ \\
\hline
\end{tabular}

Induk kambing yang menunjukkan gejala birahi setelah penyuntikan PGF2 $\alpha$ pertama yaitu sebanyak 8 ekor (40\%). Hal ini disebabkan induk kambing dalam fase luteal sehingga akan diregresi oleh PGF2 $\alpha$ sehingga 2-3 hari kemudian induk kambing akan mengalami birahi. Hal ini disebabkan induk kambing dalam dalam fase folikuler atau induk kambing tidak mempunyai korpus luteum fungsional dalam ovariumnya yaitu induk kambing yang berada pada stadium awal dari siklus birahi, dimana korpus luteum ada dalam kondisi mulai tumbuh. Pada keadaan demikian PGF2 $\alpha$ tidak mampu menghancurkan sel lutein dari korpus luteum, dengan kata lain PGF2 $\alpha$ sangat efektif untuk dipakai gertakan birahi pada ternak dalam fase diestrus sebab pada fase ini terdapat korpus luteum yang sedang menurun fungsinya. Pada penyuntikan PGF2 $\alpha$ kedua ternyata 20 ekor (100\%) induk kambing mengalami birahiserentak. Hal ini disebabkan karena semua induk kambing ada dalam kondisi dimana korpus luteumnya sedang menurun sehingga penyuntikan PGF2 $\alpha$ pertama mempunyai efek maksimal yaitu meregresi korpus luteum dan akan diikuti pertumbuhan folikel sehingga timbul gejala birahi. Menurut Hariadi et al, (2011) induk kambing pada penyuntikan PGF2 $\alpha$ pertama dalam fase luteal maupun fase folikuler, pada hari ke 11 penyuntikan PGF2 $\alpha$ kedua, semua induk kambing dalam fase luteal sehingga semua induk kambing mengalami birahi secara bersamaan.

\section{Inseminasi Buatan pada Induk Kambing Tanpa Superovulasi}

Setelah dilakukan penyerentakan birahi pada induk kambing menggunakan PGF2 $\alpha$ selanjutnya dilakukan inseminasi buatan pada induk kambing yang birahi setelah penyuntikan PGF2 $\alpha$ kedua menggunakan semen segar pejantan Etawa. Hasilnya dapat dilihat pada Tabel 2.

Hasil dari kawin suntik menggunakan semen segar terhadap 10 ekor induk kambing, ternyata 10 ekor (100\%) induk kambing bunting. Jumlah anak sebanyak 16 ekor sedangkan yang mati sebanyak 0 ekor $(0 \%)$ sedangkan yang hidup sebanyak 16 ekor (100\%). Anak kambing berjenis kelamin jantan 9 ekor $(56,25 \%)$ dan berjenis kelanin betina 7 ekor (43,75\%). Hal ini tidak sesuai pendapat Hafez (2008) yang menyatakan bahwa anak yang dilahirkan berjenis kelamin jantan maupun betina sebesar 50\% : 50\%. Hal ini disebabkan pejantan kambing banyak mengandung spermatozoa Y.

\section{Inseminasi Buatan pada Induk Kambing setelah Superovulasi}

Setelah dilakukan penyerentakan birahi terhadap 10 ekor induk kambing menggunakan PGF2 $\alpha 5 \mathrm{mg}$ /ekor dan superovulasi menggunakan PMSG 500 IU dan HCG 250 IU pada induk kambing selanjutnya dilakukan inseminasi buatan pada induk kambing yang birahi setelah penyuntikan PGF2 $\alpha$ kedua menggunakan semen segar pejantan Etawa. Hasilnya dapat dilihat pada Tabel 3.

Hasil dari kawin suntik menggunakan semen segar terhadap 10 ekor induk kambing dilakukan superovulasi , ternyata induk kambing bunting sebanyak 10 ekor (100\%). Jumlah anak sebanyak 30 ekor (rata-rata 3), sedangkan yang mati sebanyak 2 ekor $(6,67 \%)$. Anak yang hidup sebanyak 28 ekor $(93,33 \%)$, berjenis kelamin jantan sebanyak 13 ekor (40,61\%) dan betina sebanyak 15 ekor (59,39\%). Hal ini sesuai pendapat Hafez (2008) yang menyatakan bahwa anak yang dilahirkan berjenis kelamin jantan maupun betina

Tabel 2. Jumlah induk kambing bunting, jumlah anak dan jenis kelamin anak yang dilahirkan setelah IB menggunakan semen segar

\begin{tabular}{cccccc}
\hline \multirow{2}{*}{ Tidak bunting } & \multirow{2}{*}{ Bunting } & \multirow{2}{*}{ Anak hidup } & \multirow{2}{*}{ Anak mati } & \multicolumn{2}{c}{ Jenis Kelamin } \\
\cline { 5 - 6 } & & 10 & 0 & Jantan & Betina \\
\hline 0 & $100 \%$ & $100 \%$ & $0 \%$ & $56,25 \%$ & $43,75 \%$ \\
\hline
\end{tabular}

Tabel 3. Jumlah induk kambing bunting, jumlah anak dan jenis kelamin anak yang dilahirkan setelah IB menggunakan semen segar

\begin{tabular}{|c|c|c|c|c|c|}
\hline \multirow{2}{*}{ Tidak bunting } & \multirow{2}{*}{ Bunting } & \multirow{2}{*}{ Anak hidup } & \multirow{2}{*}{ Anak mati } & \multicolumn{2}{|c|}{ Jenis Kelamin } \\
\hline & & & & Jantan & Betina \\
\hline 0 & 10 & 28 & 2 & 13 & 15 \\
\hline $0 \%$ & $100 \%$ & $93,33 \%$ & $6,67 \%$ & $40,61 \%$ & $59,39 \%$ \\
\hline
\end{tabular}


sebesar 50\% : 50\%, artinya kemungkinannya anak yang dilahirkan berjenis kelamin jantan dan betina adalah sama.

Superovulasi yang dilakukan menggunakan PMSG dan HCG tidak selalu memberikan hasil yang memuaskan karena adakalanya akibat dari superovulasi tersebut tidak diikuti dengan seluruh folokel menjadi pecah sehingga terbentuk folikel sistik disertai dengan terjadinya birahi berkepanjangan. Menurut Hafez (2008) induk kambing dapat dilakukan superovulasi sebanyak 3 kali berturut-turut akan diikuti. Pemberian PMSG berturut-turut akan diikuti respon ovarium yang menurun akibat timbulnya anti PMSG dalam darahnya. Menurut Wurlina et al (2012) menyatakan superovulasi berulang pada kambing menyebabkan respon ovarium akan berkurang sehingga jumlah sel telur yang diovulasikan akan makin menurun. Hal ini disebabkan oleh produksi antibodi terhadap gonadotropin dalam tubuh induk kambing. Apabila pemberian PMSG disertai dengan Freud's Adjuvant, jumlah superovulasi tidak terpengaruh walauun antibody terhadap PMSG dapat terbentuk. Untuk menghindari terjadinya penurunan respon ovarium terhadap PMSG dapat diatasi dengan menambah dosis PMSG pada pemberian berikutnya.

Hasil dari inseminasi buatan pada kambing 100\% induk bunting. Apabila tidak terjadinya kebuntingan pada induk kambing disebabkan berbagai macam faktor yaitu : kematian embrio dini, kelainan anatomi, pakan yang kurang dan gangguan hormonal. Kematian anak kambing disebabkan saat anak kambing lahir, peternak terlambat mengeluarkan lendir yang ada didalam mulutnya, induk tidak mau menyusui karena baru pertama melahirkan serta anak kambing kejangkejang dan dugaan sementara radang pada tali pusar.

\section{Penggemukan kambing PE menggunakan pakan tanpa hijauan}

Penggemukan kambing jantan PE sebanyak 10 ekor menggunakan pakan hijaun dan growth promotor sebesar 252,35 gram/ekor perhari.

Kandungan dari empon-empon sebagai growth promoter yang merupakan enzim protease yang bersifat proteolitik yang mampu memecah protein, protease dan peptida. Kandungan empon-empon dapat mengadakan reaksi kompleks dengan protein dan reaksi yang terjadi dapat bersifat hidrolisa protein, sintesis protein, reaksi transferase. Empon- empon menyebabkan hidrolisa protein secara sempurna menjadi asam amino bebas. Empon-empon memecah protein menjadi peptida yang selanjutnya menghasilkan asam amino dan amonia. Amonia tersebut digunakan oleh mikroba rumen ternak ruminansia untuk memecah serat kasar. Selain itu bromelin dapat langsung bereaksi dengan mikroba membentuk protein mikroba sehingga kerja dari rumen dalam memecah partikel makanan dapat meningkat dan lebih efektif, sehingga hasil dari pemecahan partikel makanan tersebut dapat digunakan oleh tubuh untuk keperluan pertumbuhan dan peningkatan produksi sehingga peningkatan berat badan ternak menjadi cepat dan ternak menjadigemuk.

Mekanisme kerja empon-empon dalam rumen adalah sebagai berikut : produk akhir dari makanna dalam rumen adalah Volatyl Fatty Acid (VFA) atau asam lemak terbang, karbon dioksida dan methan. Asam lemak terbang terdiri dari asetat, propionat dan butirat. Energi yang hilang sebagai panas dan methan. ATP diproduksi dengan mengubah makanan menjadi asam lemak dan unsuryang lain untuk pertumbuhan sel. ATP merupakan energi utama untuk pertumbuhan mikroorganisme. Karbohidrat yang berupa pati, gula dan serat kasar akan difermentasikan dalam rumen menjadi asam lemak, karbon doksida dan methan.

\section{SIMPULAN}

Penyerentakan birahi dengan penyuntikan PGF2 $\alpha$ dosis $5 \mathrm{mg} / \mathrm{ekor}$ sebanyak dua kali interval 11 hari menyebabkan induk kambing sebanyak 40\% menunjukkan gejala birahi setelah penyuntikan PGF2 $\alpha$ pertama dan sebesar $100 \%$ menunjukkan gejala birahi setelah penyuntikan PGF2 $\alpha$ kedua. Terjadinya kebuntingan pada induk kambing tanpa superovulasi dan di superovulasi setelah Inseminasi buatan menggunakan semen segar sebesar 100\%. Pada induk tanpa superovulasi dengan jumlah anak hasil IB sebanyak 16 ekor (rata- rata 1,6), yang mati sebanyak 0 ekor $(0 \%)$, berjenis kelamin jantan 9 ekor $(56,25 \%)$ dan kelamin betina 7 ekor (43,75\%). Sedangkan pada induk di superovulasi dengan jumlah anak hasil IB sebanyak 30 ekor (rata-rata 3), sedangkan yang mati sebanyak 2 ekor $(6,67 \%)$. Anak yang hidup sebanyak 28 ekor (93.33\%), berjenis kelamin jantan sebanyak 13 ekor $(40,61 \%)$ dan betina sebanyak 15 ekor $(59,39 \%)$.

\section{UCAPAN TERIMA KASIH}

Penulis mengucapkan terima kasih kepada DIPA Universitas Airlangga Tahun Anggaran 2015 sesuai dengan Surat Keputusan Rektor Universitas Airlangga Tentang Pelaksanaan Hibah Kegiatan Penelitian dan Program Pengabdian Kepada Masyarakat Baru dan Lanjutan Nomor 519/UN3/2015, Tanggal 26 Maret 2015

\section{DAFTAR PUSTAKA}

Hafez.E.S.E. 2008. Reproduction in Farm Animal. Philadelphia: Lea and Febiger.

Hariadi M, Hardjopranjoto,S, Wurlina, Hermadi A.H, Rimayanti, Triana I.N, Ratnani H dan Utomo B .2011. Ilmu Kemajiran Pada Ternak. Surabaya: Airlangga University Press. 
Junjungan, S, 1.P. batubara, S.P. Ginting, E.Sihite, K. Simanjuntak, A. tarigan dan D.Sihombing. 2002. Analisis Potensi Ekonomi Limbah dan hasil Ikutan Perkebunan Kelapa sawit Sebagai Pakan Kambing Potong Lokal Penelitian kambing Potong Sumbar.

Karo. S.K. 2005. Kontribusi Usaha Peternakan Kambing dalam Pembangunan Pertanian. Loka Penelitian Kambing Potong. Pusat Penelitian dan Penembangan Peternakan.

Meles D.K, Wurlina, Mulyati S dan Ratnani H. 2010. Penggemukan Kambing Peranakan Etawa secara Agroondustri di Kabupaten Blitar. Iptekda-Lipi.
Meles D.K, Wurlina, Ratnani H dan Mulyati S 2011. Usaha Pembibitan dan Penggemukan Kambing Peranakan Etawa di Kabupaten Blitar. Iptekda-LIPI

Wurlina, D.K. Meles dan K.Rachmawati. 2012. Ipteks bagi Masyarakat. Budi daya Ternak Kambing. Surabaya: Airlangga University Press.

Wurlina, H Ratnani, D.K. Meles. 2005. Kawin Suntik pada Kambing Menggunakan Semen beku kambing Boar. Iptek. Unair

Wurlina, K. Rachmawati dan D.K. Meles. 2003. kawin suntik Pada Kmbing dan Domba. LPPM Unair.

Yusdja Y. 2006. Prospek Usaha Peternakan kambing Menuju 2020. Puslitbang Sosial Ekonomi Pertanian. Badan Penelitian dan Pengembangan Pertanian. 